\title{
Reduced Root-zone Phosphorus Concentration Decreases Iron Chlorosis in Maize in Soilless Substrates
}

\author{
Christopher Parry ${ }^{1,2,3}$ and Bruce Bugbee ${ }^{1}$
}

ADDITIONAL INDEX WORDs. chlorosis, chlorophyll concentration, ceramic substrate, sphagnum peat/vermiculite substrate

SuMMARY. Maize (Zea mays) is increasingly grown in controlled environments to facilitate phenotypic analysis. Even with ample chelated iron ( $\mathrm{Fe})$, maize often develops interveinal chlorosis in soilless substrates or hydroponics because of inadequate bioavailable $\mathrm{Fe}$ in the plant. We hypothesized that the excessive phosphorus $(P)$ in standard greenhouse fertigation solutions would accentuate the chlorosis. Here, we report that reducing the $\mathrm{P}$ concentration from 0.7 to $0.07 \mathrm{mmol} \cdot \mathrm{L}^{-1}\left(22\right.$ to $\left.2 \mathrm{mg} \cdot \mathrm{L}^{-1}\right)$ provided adequate $P$ for rapid growth and increased chlorophyll concentration from 263 to $380 \mu \mathrm{mol} \cdot \mathrm{m}^{-2}$. Restricted root-zones in containers require frequent watering and are often watered to excess, which flushes the root-zone with a high $P$ solution. In a separate study, minimizing the leaching fraction increased leaf chlorophyll concentration from 123 to $508 \mu \mathrm{mol} \cdot \mathrm{m}^{-2}$. The use of a ceramic substrate typically improves the green leaf color of maize plants. Consistent with this observation, we found no effect of high $\mathrm{P}$ concentration in the irrigation solution on growth or chlorophyll density in ceramic substrates because it strongly absorbs $\mathrm{P}$ from solution. These findings can significantly improve maize growth and nutrition in controlled environments.

M aize is now widely grown in containers in greenhouses to facilitate phenotypic analysis. Fe chlorosis regularly occurs in maize cultivars (both field and sweet maize cultivars) with fertilization and irrigation practices that result in dark green leaves of dicot species (M. de Carbonnel, personal communication; J.M. Frantz, personal communication).

Bioavailable $\mathrm{Fe}$ is required for the synthesis of chlorophyll and the lack of Fe causes yellowing of leaf tissue known as $\mathrm{Fe}$ chlorosis. This relationship is so closely linked that chlorophyll synthesis is often a sensitive indicator of $\mathrm{Fe}$ bioavailability (Boyd et al., 2007; Stocking, 1975; Thoiron et al., 2002). There are two strategies by which plants acquire Fe in the rhizosphere. Using Strategy I, dicots solubilize and reduce ferric Fe $\left(\mathrm{Fe}^{3+}\right)$ by lowering the rhizosphere $\mathrm{pH}$ when $\mathrm{Fe}$ is deficient. Graminaceous monocots, including maize,

This work was supported by the Utah Agricultural Experiment Station, Utah State University.

${ }^{1}$ Department of Plants, Soils, and Climate, Utah State University, Logan, UT 84322

${ }^{2}$ USDA-ARS, Department of Viticulture and Enology, University of California Davis, Davis, CA 95616

${ }^{3}$ Corresponding author. Christopher.k.parry@gmail. com.

doi: 10.21273/HORTTECH03735-17 use Strategy II by secreting mugineic acid family phytosiderophores (Mas) that bind $\mathrm{Fe}^{3+}$ and bring it into a solution in response to $\mathrm{Fe}$ deficiency (Ishimaru et al., 2006; Morrissey and Guerinot, 2009).

It is difficult to determine the bioavailabity of $\mathrm{Fe}$ by the analysis of total $\mathrm{Fe}$ in plant tissue analysis. Fe can be precipitated by soluble $\mathrm{P}$ in the xylem (Chandler and Scarseth, 1941; Mathan and Amberger, 1977) resulting in leaves with $\mathrm{Fe}$ chlorosis that have higher total $\mathrm{Fe}$ concentrations than nonchlorotic leaves (Abadia et al., 2011). Bennett (1945) appears to have been the first person to speculate that the uptake of excess $P$ contributed to inactivation of $\mathrm{Fe}$ in plants. Sánchez-Rodríguez et al. (2014) found that elevated $P$ on calcareous soils increased $\mathrm{Fe}$ chlorosis in lupin (Lupinus albus). Brown and
Olsen (1980) used phosphate to induce Fe chlorosis in maize because it also inhibits the reduction of $\mathrm{Fe}^{3+}$ to ferrous $\mathrm{Fe}\left(\mathrm{Fe}^{2+}\right)$. Although they observed that $\mathrm{P}$ inhibited the reduction of $\mathrm{Fe}^{3+}$ to $\mathrm{Fe}^{2+}$, they did not provide an explanation into how it happens.

The $\mathrm{P}$ concentration from a standard $20 \mathrm{~N}-4.4 \mathrm{P}-16.6 \mathrm{~K}$ greenhouse liquid fertilizer, applied at $7.14 \mathrm{mmol} \cdot \mathrm{L}^{-1}$ nitrogen $(\mathrm{N})\left(100 \mathrm{mg} \cdot \mathrm{L}^{-1}\right.$; typical for liquid feed in soilless substrates), provides $0.7 \mathrm{mmol} \cdot \mathrm{L}^{-1}\left(22 \mathrm{mg} \cdot \mathrm{L}^{-1}\right) \mathrm{P}$. This is more than 10 times higher than the $\mathrm{P}$ concentration in agricultural field soil solutions, which is typically less than $0.07 \mathrm{mmol} \cdot \mathrm{L}^{-1}\left(2 \mathrm{mg} \cdot \mathrm{L}^{-1}\right)$.

Increasing the concentration of chelated $\mathrm{Fe}$ [e.g., ethylenediamine-N, $\mathrm{N}^{\prime}$-bis (EDDHA), diethylenetriaminepentaacetic acid (DTPA), and ethylenediaminetetraacetic acid] in the fertigation solution for soilless substrates is expensive and marginally effective for graminaceous monocots at increasing leaf chlorophyll concentration (green color), so other approaches are needed. We hypothesized that reducing fertilizer $\mathrm{P}$ concentration and watering frequency would reduce $\mathrm{Fe}$ chlorosis of maize without reducing growth in controlled environments where maize is typically grown in containers with soilless substrates. The objectives of this study were to 1) determine the effect of reducing fertilizer $\mathrm{P}$ concentration on maize Fe chlorosis; 2) compare the effect of two soilless substrates on maize Fe chlorosis; and 3) determine the effect of leaching fraction (percent) on maize chlorosis.

\section{Materials and methods}

All studies were conducted in a spatially uniform greenhouse environment in the Research Greenhouse Complex at Utah State University, Logan (lat. $41.7^{\circ} \mathrm{N}, 111.8^{\circ} \mathrm{W}$ ). To achieve rapid growth rates in all studies, supplemental lighting from

\begin{tabular}{llll}
\hline $\begin{array}{l}\text { Units } \\
\begin{array}{l}\text { To convert U.S. to SI, } \\
\text { multiply by }\end{array}\end{array}$ & U.S. unit & SI unit & $\begin{array}{l}\text { To convert SI to U.S., } \\
\text { multiply by }\end{array}$ \\
\hline 10 & $\%$ & $\mathrm{~g} \cdot \mathrm{kg}^{-1}$ & 0.1 \\
1 & $\mathrm{cbar}$ & $\mathrm{kPa}$ & 1 \\
0.0929 & $\mathrm{ft}^{2}$ & $\mathrm{~m}^{2}$ & 10.7639 \\
3.7854 & $\mathrm{gal}$ & $\mathrm{L}$ & 0.2642 \\
28.3495 & $\mathrm{OZ}$ & $\mathrm{g}$ & 0.0353 \\
1 & $\mathrm{ppm}$ & $\mathrm{mg} \cdot \mathrm{kg}^{-1}$ & 1 \\
1 & $\mathrm{ppm}$ & $\mathrm{mg} \cdot \mathrm{L}^{-1}$ & 1 \\
$\left({ }^{\circ} \mathrm{F}-32\right) \div 1.8$ & ${ }^{\circ} \mathrm{F}$ & ${ }^{\circ} \mathrm{C}$ & $\left({ }^{\circ} \mathrm{C} \times 1.8\right)+32$
\end{tabular}


high-pressure sodium lamps provided a minimum daily light integral of $17 \mathrm{~mol} \cdot \mathrm{m}^{-2} \cdot \mathrm{d}^{-1}$. The high level of supplemental lighting distinguishes this research greenhouse from a standard production greenhouse. This DLI is much higher than a typical production greenhouse, but is typical of research greenhouses with maize, where rapid growth rates are desired. Day and night temperatures were controlled at $25 / 20^{\circ} \mathrm{C}$ (day/night), with a vapor pressure deficit of $1.7 / 0.8 \mathrm{kPa}$ (day/night).

Leaf chlorophyll concentration was measured in all studies with a nondestructive optical meter (model CCM-200; Opti-Sciences, Hudson, $\mathrm{NH})$. This meter measures the transmission of two wavelengths of radiation through plant leaves: red at $\approx 650 \mathrm{~nm}$ and near IR at $\approx 900 \mathrm{~nm}$. Increased chlorophyll concentration increases absorption of the red radiation (Parry et al., 2014). This meter outputs a chlorophyll index (ratio of wavelengths) that is similar to other hand-held chlorophyll meters [Soil Plant Analysis Division (SPAD) meter (model 502; Konica-Minolta Corp, Tokyo, Japan)]. Unfortunately, these indexes are nonlinearly related to the chlorophyll concentration in the leaf, so the meter output was converted from chlorophyll content index to absolute chlorophyll concentration (micromoles per square meter) using the maize conversion equation described by Parry et al. (2014). Parry et al. (2014) also describes an equation for converting SPAD index values to chlorophyll concentration. Three to five measurements were made on the most recent fully developed leaf for each plant in each replicate pot in all trials.

The leaf tissue nutrient content was analyzed by an inductively coupled plasma-optical emission spectrometry [ICP-OES (Thermo IRIS Intrepid II; Thermo Scientific, Waltham, MA)]. Fully expanded leaves and the stems from each of three replicate plants from each of four replicate containers (12 leaves) were combined for analysis in each study $30 \mathrm{~d}$ after planting. After drying the leaves at $80{ }^{\circ} \mathrm{C}$, the leaves were ground to a fine powder and digested with $30 \%$ hydrogen peroxide for ICPOES analysis. Nutrient analysis for roots was not performed for any of the three studies.
Phosphorus treatment study. Each treatment included three plants in each of four replicate, 2 -L pots with a $1: 1$ volumetric ratio of a sphagnum peat/vermiculite soilless substrate. This substrate has been widely used in greenhouse production because it provides a high cation exchange capacity, it provides silicon and has excellent water holding capacity. The substrate $\mathrm{pH}$ with vermiculite is about $\mathrm{pH} 6$ so no supplemental lime is needed as is common with a sphagnum peat/perlite substrate. Following standard greenhouse practices, the substrate was watered once daily to $33 \%$ leaching fraction, which was determined by measuring the leachate in a tray under the pot. Two fertilizers with identical micronutrients $[20 \mathrm{~N}-$ $2.2 \mathrm{P}-16.6 \mathrm{~K}$ and $20 \mathrm{~N}-0.4 \mathrm{P}-16.6 \mathrm{~K}$ (Proven Winners, Sycamore, IL)] were applied at $7.14 \mathrm{mmol} \cdot \mathrm{L}^{-1} \cdot \mathrm{N} \quad(100$ $\left.\mathrm{mg} \cdot \mathrm{L}^{-1}\right)$. For both fertilizers, the nitrate and ammonium concentrations were each at $10 \%$. This provided 0.35 and $0.07 \mathrm{~mm}$ of $\mathrm{P}\left(11\right.$ and $\left.2.2 \mathrm{mg} \cdot \mathrm{L}^{-1}\right)$ [provided from diphosphorous pentoxide $\left.\left(\mathrm{P}_{2} \mathrm{O}_{5}\right)\right]$ in the irrigation solution of the two treatments. Water for the solution was Logan, UT tap water. Chelated Fe from EDDHA $(5 \mu \mathrm{M})$ was added to both $\mathrm{P}$ treatments to provide ample chelated $\mathrm{Fe}$ in the irrigation solution in addition to the $0.1 \%$ Fe (FE DTPA) provided from each fertilizer. Leaf chlorophyll concentration and nutrient content were measured $30 \mathrm{~d}$ after planting (day of sowing). The plants were thinned to one plant per pot at the time the photographs were taken, after chlorophyll and nutrient measurements had been taken. The maize cultivar LL8652 (Syngenta, Greensboro, $\mathrm{NC}$ ) has been widely used for tests in greenhouse environments and was used in these studies. Previous studies indicated that this cultivar has a response to $\mathrm{Fe}$ that is typical of all maize cultivars, including sweet maize cultivars.

SUBSTRATE COMPARISON STUDY. Two types of soilless substrates were compared: a baked ceramic clay (Profile $^{\circledR}$; Profile Products, Buffalo Grove, IL) and a volumetric ratio of 1:1 peat/vermiculite. There were three maize plants in each of four replicate pots for each treatment. P concentration in the irrigation solution $(20 \mathrm{~N}-$ $2.2 \mathrm{P}-16.6 \mathrm{~K}$ and $20 \mathrm{~N}-0.4 \mathrm{P}-16.6 \mathrm{~K})$, pot size, chelated $\mathrm{Fe}$, and leaching fraction were identical to the P concentration study $(\approx 33 \%)$. Leaf chlorophyll concentration, biomass, and nutrient content were measured $30 \mathrm{~d}$ after planting. Chlorophyll content measurements were made on the most recent fully expanded leaf of each plant.

LEACHING FRACTION STUDY. Plants were watered once daily to container capacity. Leaching fractions of $0 \%, 33 \%, 50 \%$, and $100 \%$ in the peat/vermiculite substrate were created by watering with different volumes of irrigation solution. The $100 \%$ leaching fraction meant that the volume of leachate was equal to the input

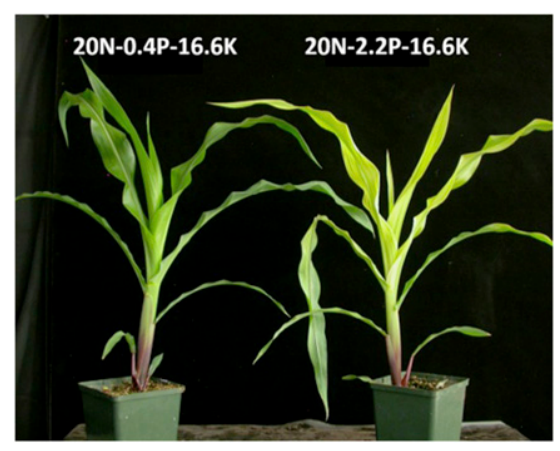

Fig. 1. Effect of two phosphorous (P) levels $(20 \mathrm{~N}-0.4 \mathrm{P}-16.6 \mathrm{~K}$ and $20 \mathrm{~N}-$ $2.2 \mathrm{P}-16.6 \mathrm{~K}$ ) on green color of maize. Plants were grown in a peat/ vermiculite soilless media. Note the increased chlorosis with higher $P$. There were four replicate containers and the plants were uniform in color among the replicate containers.

Representative plants are shown.

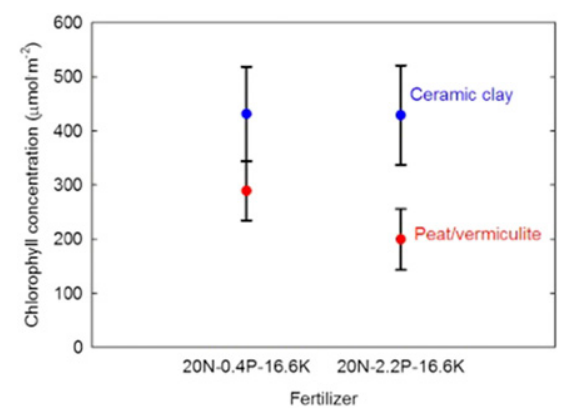

Fig. 2. Effect of two phosphorous (P) levels $(20 \mathrm{~N}-0.4 \mathrm{P}-16.6 \mathrm{~K}$ and $20 \mathrm{~N}-$ $2.2 \mathrm{P}-16.6 \mathrm{~K}$ ) on chlorophyll concentration in maize. There was no significant effect of $P$ level on chlorophyll in the ceramic clay, but there was a statistically significant and biologically important effect of $P$ level on chlorophyll concentration in the peat/vermiculite media. Error bars represent \pm SD. 
volume of fertilizer solution so that the volume of solution in the container was completely replaced with new solution each day. There were three plants in each of four replicate pots per treatment. The P concentration in the irrigation solution, chelated $\mathrm{Fe}$, and pot size were identical to the $\mathrm{P}$ concentration study. Chlorophyll was measured on the newest fully emerged leaf on each plant at harvest on day 30 .

\section{Results and discussion}

ROOT-ZONE PHOSPHORUS STUDY. Increasing $\mathrm{P}$ concentration in peat/ vermiculite increased leaf chlorosis (Fig. 1). Leaf chlorophyll concentration decreased from 380 to $263 \mu \mathrm{mol} \cdot \mathrm{m}^{-2}$ as the $\mathrm{P}$ concentration increased from 0.07 to $0.35 \mathrm{~mm}$. The typical leaf chlorophyll concentration of maize in the field is 350-500 $\mu \mathrm{mol} \cdot \mathrm{m}^{-2}$ (Parry et al., 2014). The ICP-OES analysis of leaf Fe concentrations were similar for both $\mathrm{P}$ concentrations (63 vs. $59 \mathrm{mg} \cdot \mathrm{kg}^{-1}$ ). The optimal leaf Fe concentration range is from 21 to $250 \mathrm{mg} \cdot \mathrm{kg}^{-1}$ (Jones, 1967), but measurement of total $\mathrm{Fe}$ concentration in leaves is a poor indictor of Fe bioavailability because foliar $\mathrm{Fe}$ is often not bioavailable (Abadia et al., 2011; Chandler and Scarseth, 1941; Mathan and Amberger, 1977). Chlorophyll synthesis is often a better indicator of leaf Fe bioavailability than total $\mathrm{Fe}$ concentration (Boyd et al., 2007).

As expected, $\mathrm{P}$ concentrations were higher in plants grown with higher root-zone $P$ [ 1.0 vs. $2.5 \mathrm{~g} \cdot \mathrm{kg}^{-1}$ $(0.10 \%$ vs. $0.25 \%)]$, but there was no statistically significant effect of $\mathrm{P}$ concentration on the shoot fresh or dry weight (data not shown), which indicates that the lower $\mathrm{P}$ level was adequate to support optimal growth. Acceptable $\mathrm{P}$ concentration in maize leaves is $0.25 \%$ to $0.40 \%$ (Jones, 1967).

SubSTRATE COMPARISON STUDY. Maize grown in the ceramic substrate was visually less chlorotic and had higher chlorophyll than the maize grown in the peat/vermiculite substrate for both fertilizer treatments. Chlorophyll content was similar at both $\mathrm{P}$ levels in the ceramic substrate (431 and $429 \mu \mathrm{mol} \cdot \mathrm{m}^{-2}$ ) but decreased from 290 to $200 \mu \mathrm{mol} \cdot \mathrm{m}^{-2}$ in the peat/vermiculite substrate (Fig. $2)$. There was no significant difference in leaf greenness between the two ceramic substrate treatments (Fig. 3).
As expected, leaf tissue $P$ levels increased with increasing $P$, but the leaf $\mathrm{P}$ concentration was adequate in ceramic substrate at both $P$ levels $(0.17 \%$ for the $20 \mathrm{~N}-0.4 \mathrm{P}-16.6 \mathrm{~K}$ fertilizer and $0.36 \%$ for the $20 \mathrm{~N}-2.2 \mathrm{P}-16.6 \mathrm{~K}$ fertilizer). There was no statistically significant effect of $\mathrm{P}$ level on the shoot dry weight for either the peat/vermiculite $(1.5$ vs. $1.7 \mathrm{~g})$ or the ceramic clay substrate ( 1.3 vs. $1.4 \mathrm{~g}$ ). Roots were not measured.

Chen et al. (2016) found that nutrient imbalance caused by a low content of active $\mathrm{Fe}$ and a high content of active manganese $(\mathrm{Mn})$ in the leaves of sugarcane in acid soil was a major reason for chlorosis, but the Mn concentration of the maize leaves was optimal in these studies, and the $\mathrm{Fe}: \mathrm{Mn}$ ratio is not likely the cause of the chlorosis.

Adams et al. (2014) demonstrated that ceramic aggregates strongly absorb $\mathrm{P}$ from irrigation solutions, and this rapid sorption of $\mathrm{P}$ from the irrigation solution likely improved the bioavailable $\mathrm{Fe}$ and leaf chlorophyll concentration.

LEACHING FRACTION STUDY. Limited container volumes mean that large maize plants need to be watered daily to prevent water stress. Variation in the watering rate of drip emitters means that plants are typically watered to excess to insure that all containers are watered adequately. Increasing the leaching fraction, however, linearly decreased chlorophyll content from 508 to $123 \mu \mathrm{mol} \cdot \mathrm{m}^{-2}$ $\left[r^{2}=0.97\right.$ (Fig. 4)]. Since porous soilless substrates drain to the container capacity within minutes after irrigation, this is not likely caused by excess water in the root-zone. Excess soil moisture, however, often increases Fe chlorosis. Misra and Tyler (1999) suggested that increased soil moisture in the field may lead to increased degradation of siderophores and decreased concentrations of $\mathrm{Fe}$ in shoots. Marschner et al. (1986) found that siderophores were degraded by microbes at high soil moisture content. In the current study, decreased chlorophyll in the higher leaching fraction may be caused by leaching of siderophores from the rhizosphere, but it may also be associated with increased $\mathrm{P}$ in the root-zone solution, iron phosphate $\left(\mathrm{FePO}_{4}\right)$ precipitation, and a reduction of bioavailable Fe. Misra and Tyler (1999) also found that high soil moisture content caused increased uptake of $\mathrm{P}$ and increased the P:Fe ratio in the plant, which can lead to internal

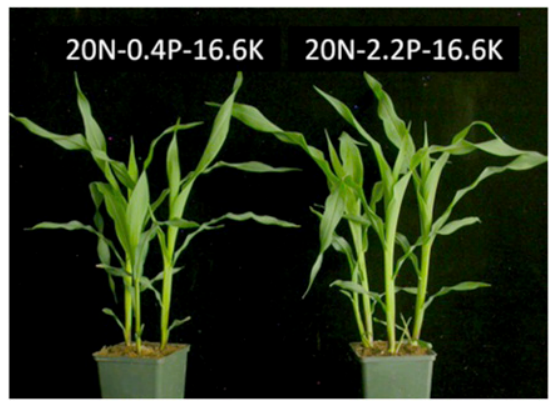

Fig. 3. Maize grown in a baked ceramic clay media with two phosphorous $(\mathrm{P})$ levels $(20 \mathrm{~N}-0.4 \mathrm{P}-$ $16.6 \mathrm{~K}$ and $20 \mathrm{~N}-2.2 \mathrm{P}-16.6 \mathrm{~K})$. There was no significant effect of $P$ concentration on green color. This is likely because of strong adsorption of $\mathbf{P}$ by the ceramic media. There were four replicate containers, and the plants were uniform in color among the replicate containers.

Representative plants are shown.
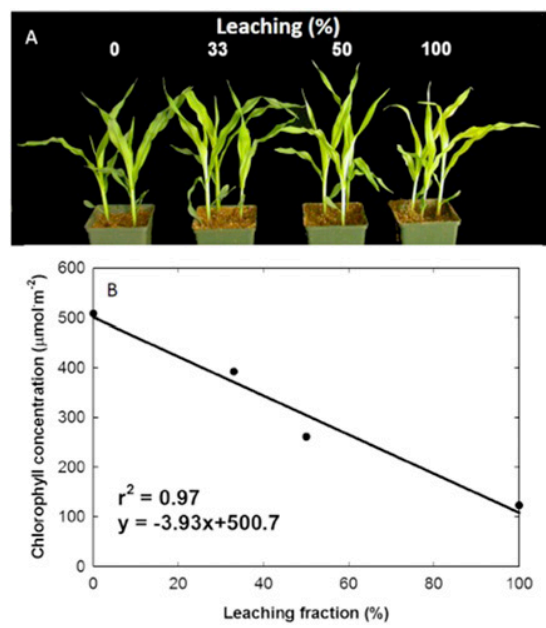

Fig. 4. (A) Maize grown in a peat/ vermiculite soilless media with four leaching fractions. All treatments were watered with the $20 \mathrm{~N}-2.2 \mathrm{P}-$ $16.6 \mathrm{~K}$ fertilizer solution.

Representative plants are shown. (B) The effect of leaching fraction on chlorophyll concentration. There were four replicate containers and the plants were uniform in color among the replicate containers. A linear regression analysis (Sigma Plot; Systat Software, San Jose, CA) showed a strong relationship between leaching fraction and leaf chlorophyll concentration with a high coefficient of determination $\left(r^{2}=0.97\right)$. 
precipitation (Inskeep and Bloom, 1986; Mengel et al., 1984).

\section{Conclusions}

Reducing root-zone $\mathrm{P}$ increased leaf chlorophyll content. When grown in baked ceramic clay soilless substrate, elevated $\mathrm{P}$ in the irrigation solution did not affect chlorophyll content or leaf greenness likely because of the rapid absorption of $\mathrm{P}$ to the substrate. Increased leaching significantly increased interveinal chlorosis likely due to elevated $\mathrm{P}$ in the root-zone and possible leaching of the siderophores from the rhizosphere.

These results suggest that reducing excess root-zone $\mathrm{P}$ in greenhouse irrigation solutions can decrease $\mathrm{Fe}$ precipitation in the rhizosphere and in the plant. Reduced $\mathrm{FePO}_{4}$ precipitation increases the bioavailability of $\mathrm{Fe}$ and decreases chlorosis.

\section{Literature cited}

Abadia, J., S. Vazquez, R. Rellan-Alvarez, H. El-Jendoubi, A. Abadia, A. AlvarezFernandez, and A.F. Lopez-Millan. 2011. Towards a knowledge-based correction of iron chlorosis. Plant Physiol. Biochem. 49:471-482.

Adams, C., A. Jacobson, and B. Bugbee. 2014. Ceramic aggregate sorption and desorption chemistry: Implications for use as a component of soilless media. J. Plant Nutr. 37:1345-1357.

Bennett, J.P. 1945. Iron in leaves. Soil Sci. 60:91-106.

Boyd, P.W., T. Jickells, C.S. Law, S. Blain, E.A. Boyle, K.O. Buesseler, K.H. Coale,
J.J. Cullen, H.J.W. De Baar, M. Follows, M. Harvey, C. Lancelot, M. Levasseur, N.P. J. Owens, R. Pollard, R.B. Rivkin, J. Sarmiento, V. Schoemann, V. Smetacek, S. Takeda, A. Tsuda, S. Turner, and A.J. Watson. 2007. Mesoscale iron enrichment experiments 1993-2005: Synthesis and future directions. Science 315:612-617.

Brown, J.C. and R.A. Olsen. 1980. Factors related to iron uptake by dicotyledonous and monocotyledonous plants III. Competition between root and external factors for Fe. J. Plant Nutr. 2:661-682.

Chandler, W.V. and G.D. Scarseth. 1941. Iron starvation as affected by overphosphating and sulfur treatment on Houston and Sumter clay soils. Agron. J. 33:93-104

Chen, G.F., Z. Liu, and Y.Y. Huang. 2016. Factors responsible for sugarcane ratoon chlorosis in acid soil and its management in Guangxi province of China. Sugar Technol. 18:500-504.

Inskeep, W.P. and P.L. Bloom. 1986. Effects of soil moisture on soil $\mathrm{pCO}_{2}$, soil solution bicarbonate and iron chlorosis in soybeans. Soil Sci. Soc. Amer. J. 50:946952.

Ishimaru, Y., M. Suzuki, T. Tsukamoto, K. Suzuki, M. Nakazono, T. Kobayashi, Y. Wada, S. Watanabe, S. Matsuhashi, M. Takahashi, H. Nakanishi, S. Mori, and N.K. Nishizawa. 2006. Rice plants take up iron as an $\mathrm{Fe}^{3+}$-phytosiderophore and as $\mathrm{Fe}^{2+}$. Plant J. 45:335-346.

Jones, J.B., Jr. 1967. Interpretation of plant analysis for several agronomic crops, p. 49-58. In: G.H. Hardy (ed.). Soil testing and plant analysis. Part II. Plant analysis. SSSA Special Publ. Ser. 2. Soil Sci. Soc. Amer., Madison, WI.
Marschner, H., V. Romheld, and M. Kissel. 1986. Different strategies in higher plants in mobilization and uptake of iron. J. Plant Nutr. 9:3-7.

Mathan, K.K. and A. Amberger. 1977. Influence of iron on uptake of phosphorus by maize. Plant Soil 46:413-422.

Mengel, K., M.T. Breininger, and W. Bubl. 1984. Bicarbonate, the most important factor inducing iron chlorosis in vine grapes on calcareous soil. Plant Soil 81:333-344.

Misra, A. and G. Tyler. 1999. Influence of soil moisture on soil solution chemistry and concentrations of minerals in the calcicoles Phleum phleoides and Veronica spicata grown on a limestone soil. Ann. Bot. 84:401-410.

Morrissey, J. and M.L. Guerinot. 2009. Iron uptake and transport in plants: The good, the bad, and the ionome. Chem. Rev. 109:4553-4567.

Parry, C., J.M. Blonquist, and B. Bugbee. 2014. In situ measurement of leaf chlorophyll concentration: Analysis of the optical/absolute relationship. Plant Cell Environ., doi: 10.111/pce.12324.

Sánchez-Rodríguez, A.R., M.C. del Campillo, and J. Torrent. 2014. The severity of iron chlorosis in sensitive plants is related to soil phosphorus levels. Sci. Food Agr. 94:2766-2773.

Stocking, C.R. 1975. Iron deficiency and the structure and physiology of maize chloroplasts. Plant Physiol. 55:626-631.

Thoiron, S., N. Pascal, and J.F. Briat. 2002. Impact of iron deficiency and iron re-supply during the early stages of vegetative development in maize (Zea mays). Plant Cell Environ. 20:1051-1060. 